\title{
THE PERMEABILITY OF CAPILLARIES TO SERUM CHOLESTEROL ${ }^{1}$
}

\author{
BY GEORG GEYER, FRANZ S. M. HERBST, H. THALER, AND WALTER F. LEVER
}

(From the I. Medisinische Universitätsklinik, Vienna, Austria, and the Department of Dermatology, Harvard Medical School, Boston, Mass., U. S. A.)

(Submitted for publication May 25, 1955 ; accepted November 23, 1955)

The view of Man and Peters (1) that under normal conditions the capillaries are impermeable to lipids has become widely accepted. The present investigation was undertaken in order to determine to which extent cholesterol would leave the capillaries under the influence of passive congestion and what effect the initial level of cholesterol in the serum would have on the amount of cholesterol passing through the capillary wall.

\section{REVIEW OF LITERATURE}

Landis, Jonas, Angevine, and Erb (2) in studying the permeability of the capillary walls to proteins found that very low congestion pressures resulted in the filtration of small amounts of fluid but no detectable loss of protein from the blood stream. High degrees of venous congestion, however, caused the filtration of considerable amounts of fluid and protein. Geyer, Keibl, and Kölbl (3) under similar conditions observed a selective filtration of protein molecules of different sizes through the capillary wall.

Man and Peters (1) determined the amounts of protein, fatty acids, lipid phosphorus and cholesterol in the blood serum of normal persons before and after standing quietly for half an hour. They found that during standing the concentration of the lipids in the serum increased to the same extent as the concentration of proteins and concluded that the capillary wall was impermeable to lipids. Similarly, Frey (4) regarded the capillaries as impermeable to cholesterol and lipoproteins since these substances were not detected in subcutaneous edema fluid. Geyer, Keibl, and Kölbl (3) found the capillaries impermeable to the lipid bearing proteins, namely the alpha and beta globulins, unless the capillaries had been damaged by an increase in the intracapillary pressure.

1 This investigation was supported by a research grant from the National Institute of Arthritis and Metabolic Diseases, of the National Institutes of Health, Public Health Service (PHS A-414).
On the other hand, Marble, Field, Drinker, and Smith (5) concluded that the walls of the blood capillaries were slightly permeable to some lipid substances because, after an intravenous infusion of a fat emulsion, the lymph fluid showed a slight increase in the amount of total lipids but not of cholesterol.

\section{METHODS}

Landis, Jonas, Angevine, and Erb (2) produced venous stasis of one forearm by means of a blood pressure cuff in order to determine the rate of filtration of fluid and protein from the capillaries. This procedure has also been used in this study to determine the rate of filtration of cholesterol in a number of normal individuals and patients. All tests were carried out in the morning before the subjects had had breakfast. Except for three subjects attending the out-patient department all test persons had remained in bed on the morning of the test. All subjects were kept reclining for at least half an hour before the test was started. The arm to which the pressure cuff was applied was supported by pillows in a horizontal position at the level of the body with the flexor surface turned upward. Then the armlet of a blood pressure apparatus was wrapped around the arm well above the elbow. The congesting pressure of the cuff was kept at either $40,50,60,70$ or 80 millimeters of mercury for 30 minutes. Pre-congestion blood samples were drawn from the antecubital vein before the cuff was placed into position. Post-congestion blood samples were drawn at the end of the 30 -minute test period with the congesting cuff still in position. In both samples the hematocrit value and the concentration of serum cholesterol were determined. Since the evaluation of the effect of venous congestion is based on the assumption that under test conditions erythrocytes do not pass the capillary wall some experiments in which petechiae appeared on the congested forearm have been excluded and are not mentioned in the reported series.

The relative amount of fluid lost through the capillary walls as a result of increase in intracapillary pressure was calculated from the difference in the hematocrit values in samples of blood taken before and after venous stasis by the following formula:

$$
F=100-\frac{100 \cdot \mathrm{H}_{1}}{\mathrm{H}_{2}}
$$

$\mathrm{F}=\mathrm{ml}$. of fluid lost from $100 \mathrm{ml}$. of whole blood.

$\mathrm{H}_{1}=$ Hematocrit value prior to congestion.

$\mathrm{H}_{2}=$ Hematocrit value after congestion. 
The amount of cholesterol passing from the plasma through the capillary wall was calculated by the formula used by Landis, Jonas, Angevine, and Erb (2) for the determination of protein losses:

$$
\begin{aligned}
& \Delta C h=\frac{C h_{1}\left(100-H_{1}\right)-C h_{2}\left(100-H_{2}-F\right)}{100} \\
& \Delta \mathrm{Ch}=\mathrm{mg} \text {. of cholesterol lost from } 100 \mathrm{ml} \text {. of whole }
\end{aligned}
$$

\begin{tabular}{|c|c|c|c|c|}
\hline $\begin{array}{l}\text { Subject } \\
\text { No. }\end{array}$ & $\begin{array}{l}\text { Congesting } \\
\text { pressure } \\
\text { applied } \\
\text { mm.Hg }\end{array}$ & $\begin{array}{c}\text { Ch } \\
\text { Initial } \\
\text { level of } \\
\text { serum } \\
\text { cholesterol } \\
\text { ms. } / 100 \text { ml. }\end{array}$ & $\begin{array}{c}\text { F } \\
\text { Amount } \\
\text { of fluid } \\
\text { filtered } \\
\text { from } \\
100 \mathrm{ml} \\
\text { of blood } \\
\text { ml. }\end{array}$ & 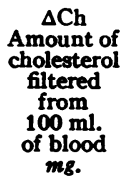 \\
\hline $\begin{array}{l}1 \\
2 \\
3 \\
4 \\
5 \\
6\end{array}$ & $\begin{array}{l}60 \\
40 \\
40 \\
60 \\
60 \\
60\end{array}$ & $\begin{array}{l}216 \\
182 \\
241 \\
242 \\
248 \\
208\end{array}$ & $\begin{array}{l}2.0 \\
4.2 \\
4.7 \\
6.2 \\
8.2 \\
9.6\end{array}$ & $\begin{array}{l}0 \\
0 \\
0 \\
0 \\
0 \\
0\end{array}$ \\
\hline $\begin{array}{c}7 \\
8 \\
9 \\
10 \\
11 \\
12 \\
13^{*} \\
14 \\
15 \\
16 \\
17 \\
18 \\
19 \\
20 \\
21 \\
22 \\
23 \\
24 \\
25 \\
26 \\
27^{*} \\
28 \\
29 \\
30 \\
31\end{array}$ & $\begin{array}{l}60 \\
60 \\
60 \\
60 \\
40 \\
60 \\
50 \\
60 \\
60 \\
60 \\
60 \\
60 \\
60 \\
60 \\
60 \\
60 \\
60 \\
60 \\
40 \\
70 \\
50 \\
80 \\
60 \\
60 \\
70\end{array}$ & $\begin{array}{l}326 \\
358 \\
208 \\
118 \\
307 \\
295 \\
400 \\
278 \\
227 \\
364 \\
204 \\
234 \\
237 \\
235 \\
269 \\
218 \\
289 \\
259 \\
319 \\
214 \\
406 \\
373 \\
319 \\
251 \\
248\end{array}$ & $\begin{array}{r}5.7 \\
7.2 \\
8.3 \\
9.1 \\
9.6 \\
10.2 \\
10.2 \\
10.2 \\
10.4 \\
10.7 \\
11.5 \\
12.1 \\
13.0 \\
13.1 \\
13.3 \\
13.7 \\
14.0 \\
14.3 \\
14.3 \\
14.7 \\
14.7 \\
15.2 \\
15.6 \\
16.0 \\
16.4\end{array}$ & $\begin{array}{r}5.0 \\
7.6 \\
8.5 \\
1.0 \\
6.0 \\
8.5 \\
14.0 \\
19.3 \\
5.7 \\
6.0 \\
3.0 \\
5.0 \\
3.0 \\
6.0 \\
8.5 \\
4.5 \\
12.9 \\
11.0 \\
30.5 \\
7.3 \\
31.5 \\
21.0 \\
22.0 \\
17.5 \\
7.3\end{array}$ \\
\hline $\begin{array}{l}32 \\
33 \\
34 \\
35 \\
36 \\
37 \\
38 \\
39^{*} \\
40\end{array}$ & $\begin{array}{l}60 \\
80 \\
60 \\
80 \\
80 \\
60 \\
80 \\
80 \\
80\end{array}$ & $\begin{array}{l}250 \\
241 \\
273 \\
264 \\
265 \\
357 \\
226 \\
430 \\
212\end{array}$ & $\begin{array}{l}18.4 \\
19.4 \\
19.6 \\
19.7 \\
20.0 \\
20.1 \\
21.3 \\
24.6 \\
25.4\end{array}$ & $\begin{array}{l}14.0 \\
12.8 \\
25.0 \\
21.0 \\
31.0 \\
40.0 \\
14.5 \\
35.0 \\
16.6\end{array}$ \\
\hline
\end{tabular}

TABLE I

Initial level of serum cholesterol and amounts of fluid and cholesterol filtered after congestion of the forearm for thirty minutes

* Patients with primary hypercholesteremic xanthomatosis.
The serum total cholesterol was determined by a modification of the Schoenheimer-Sperry method (6). The standard error of this method in our Laboratory has been $\pm 9.25 \mathrm{mg}$. per $100 \mathrm{ml}$. of serum.

\section{RESULTS}

Determinations were carried out on 40 persons (Table I). Three subjects had primary hypercholesteremic xanthomatosis. The serum cholesterol value exceeded $350 \mathrm{mg}$. per $100 \mathrm{ml}$. in seven individuals. The entire group has been divided into three sub-groups according to the amount of fluid and cholesterol which passed through the capillary walls during the test procedure:

Group I. In 6 persons (No. 1-6) small amounts of fluid and no measurable amount of cholesterol were lost through the capillary walls. The loss of fluid varied from 2.0 to $9.6 \mathrm{ml}$. per $100 \mathrm{ml}$. of blood and averaged $5.8 \mathrm{ml}$. The initial values for serum cholesterol ranged from 182 to $248 \mathrm{mg}$. per $100 \mathrm{ml}$. of serum, averaging $223 \mathrm{mg}$. The congesting pressure applied in these 6 persons was either 40 or $60 \mathrm{~mm}$. of mercury.

Group II. In 25 persons (No. 7-31) moderate amounts of fluid and varying amounts of cholesterol were lost through the capillary walls. The loss of fluid varied from 5.7 to $16.4 \mathrm{ml}$. per $100 \mathrm{ml}$. of blood, averaging $12.1 \mathrm{ml}$., and the loss of cholesterol varied from 1.0 to $31.5 \mathrm{mg}$. per $100 \mathrm{ml}$. of blood, averaging $10.9 \mathrm{mg}$. The initial values for serum cholesterol ranged from 118 to $406 \mathrm{mg}$. per $100 \mathrm{ml}$. of serum, averaging $278 \mathrm{mg}$. In five subjects the initial value for cholesterol was in excess of $350 \mathrm{mg}$. per $100 \mathrm{ml}$. of serum. The congesting pressure applied ranged from 40 to 80 mm. of mercury.

Group III. In 9 persons (No. 32-40) large amounts of fluid and usually also large amounts of cholesterol were lost through the capillary walls. The loss of fluid varied from 18.4 to $25.4 \mathrm{ml}$. per $100 \mathrm{ml}$. of blood, averaging $20.9 \mathrm{ml}$., and the loss of cholesterol varied from 12.8 to $40 \mathrm{mg}$. per 100 $\mathrm{ml}$. of blood, averaging $23.3 \mathrm{mg}$. The initial values for serum cholesterol ranged from 212 to $430 \mathrm{mg}$. per $100 \mathrm{ml}$. of serum, averaging $280 \mathrm{mg}$. In two persons the initial value for cholesterol was in excess of $350 \mathrm{mg}$. per $100 \mathrm{ml}$. of serum. The congesting pressure applied was either 60 or $80 \mathrm{~mm}$. of mercury.

A diagram designed to show the relation be- 
tween fluid loss and cholesterol loss showed rather wide scattering (Figure 1). The value for a linear correlation between the losses of fluid and cholesterol (as calculated by the coefficient of correlation) proved to be slightly smaller than the value for a parabolic correlation (as calculated by the index of correlation). The difference, however, between the values for linear and parabolic regressions was found to be insignificant by the F-test. Thus a linear regression was assumed and the following equations between the loss of fluid (F), the loss of cholesterol ( $\Delta \mathrm{Ch})$ and the initial level of total cholesterol (Ch) were calculated by the method of least mean squares :

$$
\begin{aligned}
& \text { (1) } \Delta \mathrm{Ch}=1.385 \mathrm{~F}-6.18 \\
& \text { (2) } \Delta \mathrm{Ch}=1.1875 \mathrm{~F}+0.07515 \mathrm{Ch}-24.002
\end{aligned}
$$

The coefficient of correlation between $\Delta \mathrm{Ch}$ and $F$ amounted to $r=0.71$, and the coefficient of correlation between $\Delta \mathrm{Ch}$ and $\mathrm{Ch}$ to $\mathrm{r}=0.61$. Thus, both coefficients of correlation differed significantly from $r=0$ as checked by the Student's t-test. Applying the formula used in this test,

$$
\frac{|r|}{\sqrt{1-r^{2}}} \cdot \sqrt{N-2}>t_{38}(=3.65) \text { for } 99 \%
$$

was calculated as $6.2>3.56$ for equation 1 and as $4.41>3.56$ for equation 2. The coefficient of correlation between $\mathrm{F}$ and $\Delta \mathrm{Ch}$ (equation 2) did not differ significantly from zero.

\section{DISCUSSION}

The amounts of fluid and of cholesterol lost from the blood stream under congesting pressure have been measured and the relations between cholesterol loss and fluid loss as well as between cholesterol loss and the initial level of serum cholesterol have been calculated by statistical means.

It appeared logical to correlate the rate of cholesterol filtration to the rate of fluid filtration because the amount of fluid filtered from the blood could be determined fairly accurately in the experiments. On the other hand, it seemed inadvisable to correlate the rate of cholesterol filtration to the amount of congesting pressure applied in spite of the fact that different degrees of pressure were applied to different subjects, because the degree of pressure applied represented only one of several physical factors affecting the rate

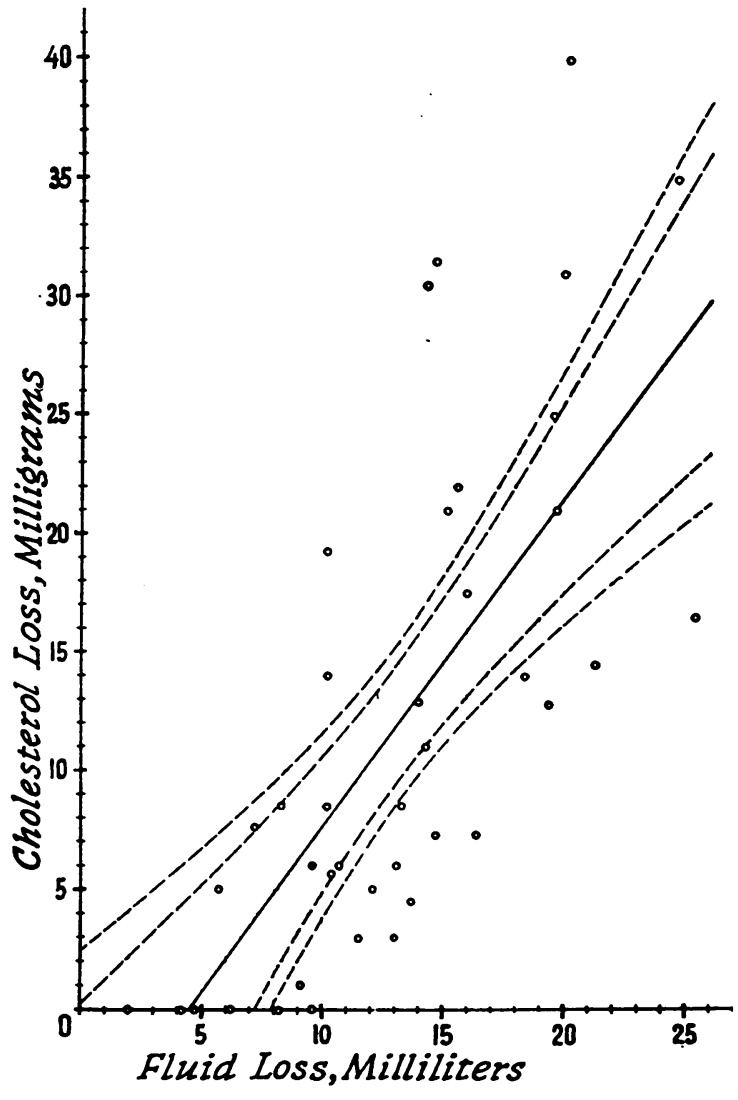

Fig. 1. Correlation Betwen the Amounts of Flum and Cholesterol Filtered Through the Capillary Walls During Congestion of the forearm for ThIRTY MINUTES

The losses of fluid and of cholesterol are calculated per $100 \mathrm{ml}$. of blood. The solid line represents an assumed linear regression while the dotted lines represent confidence limits for 95 and 99 per cent, respectively.

of cholesterol filtration. Other physical factors, such as the size and length of the pores in the capillary walls, cannot be determined in living human beings. Actually, the amount of fluid filtered through the capillary walls reflects these physical factors fairly well. Therefore, it seemed justified to consider the rate of fluid filtration as the best index of the effects of all physical influences and conditions.

In 6 of 40 subjects (Group I) venous congestion resulted in no loss of cholesterol from the blood. In all these instances only small amounts of fluid were lost. In the remaining 34 subjects (Groups II and III) cholesterol in varying amounts was found to have left the serum. A significant relation existed between the rates of 
fluid filtration and of cholesterol filtration. However, as shown by equation 2 , the rate of cholesterol filtration was influenced also by the initial level of the serum cholesterol. This was to be expected since the filtration rate of any substance is related to its concentration gradient across a filtrating membrane. The scattering of the data, as demonstrated by Figure 1, can be explained to a large extent by the considerable differences in the serum cholesterol levels of the subjects studied.

The structure of the normal capillary wall apparently permits the passage of small amounts of fluid but not of cholesterol. All cholesterol present in the serum is bound to proteins in lipoprotein molecules which are of relatively large size (7). One may conclude that the pore size of the intact capillary wall is too small to permit the passage of these large molecules. If, however, the capillary walls are damaged, as they undoubtedly are by the application of considerable congesting pressure for an extended period of time, not only large amounts of fluid but also molecules of relatively large size, such as the lipoproteins, can leave the capillaries. Thus, our studies supplement the findings of Landis and associates (2) who had observed that raising the intracapillary pressure increases the permeability of the capillaries to serum proteins.

\section{SUMMARY}

1. Calculation of the amounts of fluid and cholesterol lost through the capillary walls during pro- longed passive congestion revealed that under experimental conditions which did not significantly alter the normal capillary filtration of water no measurable amounts of cholesterol passed the capillary wall.

2. Under experimental conditions presumably inducing alterations in the capillary walls varying amounts of cholesterol were observed to pass from the circulation. The rate of cholesterol filtration showed significant relations both to the rate of fluid filtration on the one hand and to the initial level of serum cholesterol on the other.

\section{REFERENCES}

1. Man, E. B., and Peters, J. P., Permeability of capillaries to plasma lipoids. J. Clin. Invest., 1933, 12, 1031.

2. Landis, E. M., Jonas, L., Angevine, M., and Erb, W., The passage of fluid and protein through the human capillary wall during venous congestion. J. Clin. Invest., 1932, 11, 717.

3. Geyer, G., Keibl, E., and Kölbl, H., Uber Beziehungen zwischen Permeabilität und Eiweissdurchlässigkeit der Capillaren. Ztschr. exp. Med., 1953, 122, 1.

4. Handbuch der inneren Medizin, Vol. VIII, Nieren und ableitende Harnwege. Springer, Berlin, 1951.

5. Marble, A., Field, M. E., Drinker, C. K., and Smith, R. M., The permeability of the blood capillaries to lipoids. Am. J. Physiol., 1934, 109, 467.

6. Sperry, W. M., and Webb, M., A revision of the Schoenheimer-Sperry method for cholesterol determination. J. Biol. Chem., 1950, 187, 97.

7. Oncley, J. L., and Gurd, F. R. N., The lipoproteins of human plasma in Blood Cells and Plasma Proteins; Their State in Nature, James L. Tullis, Ed., New York, Academic Press, 1953, p. 337. 